\title{
The Development of Free Inquiry Lab-Based Students' Worksheet to Increase the Dimension in Science Literacy Process
}

\author{
Heleri, Risya Pramana Situmorang, Lusiawati Dewi \\ Program Studi Pendidikan Biologi, Fakultas Bologi, Universitas Kristen Satya Wacana, \\ Salatiga, Indonesia \\ e-mail: risya.situmorang@uksw.edu
}

\begin{abstract}
This research aimed at 1) developing and producing feasible free inquiry lab-based students' worksheets to increase the dimension in students' science literacy process and 2) examining the effectivity of free inquiry lab-based students' worksheets in increasing the dimension in students' science literacy process. This research was conducted using research and development method. The students of XI MIPA SMA Kristen 1 Salatiga were the subject of this research. This research was conducted in the first semester of the 2018-2019 academic year. The validation questionnaire and students' response, the observation sheet of dimension process and learning model implementation, and the science literacy question sheet were the research instrument covered in this research. The hypothesis test was conducted using the paired-sample $t$-test. The result of this research revealed that 1) the developed free inquiry lab-based students' worksheet was feasible based on the assessment result from the professional validator with the average $80.19 \%$, and the students' response was very good towards the worksheet with the assessment average $82.49 \%$. 2) The freeinquiry lab students' worksheet was effective in increasing students' dimensions in the science literacy process in plant tissue topic, which was supported with the average of students' dimension of science literacy process $87.71 \%$ (very good) and the students' N-Gain was 0.7 (very good). It was proved by the paired samples t-test statistic test with a result of $0.00<0,05$. Therefore $\mathrm{HO}$ was rejected, or in other words, the free inquiry lab-based students' worksheet was effective in increasing the dimension in the science literacy process.
\end{abstract}

Keywords: Students' Worksheet; Free Inquiry Lab; Dimension Process; Science Literacy; Plant Tissue Topic

\section{Introduction}

The twenty-first century is characterized by the development of science and sophisticated technology. Along with the development of science and technology, various challenges should be faced. One of the challenges in education is to create a qualified educational system and be able to produce qualified human resources for giving the contribution to the development (Mukminan, 2014). Therefore, it is essential to shape the competencies needed for human resources in order to be able to compete in this globalization era (Hermita, Suciati, \& Rinanto, 2016).

The vital role of education in facing the developing science and technology becomes the target in a growing and developing process of every human resources' potential (Tirtarahardja \& Sulo, 2012). Therefore, every teacher, who takes the critical, part also must be able to follow educational innovations thoroughly in order to realize the educational quality.

The development of science and technology is also supported by the development of science, especially in natural science. According to Arikunto (2006), natural science education and technology have a close relationship where natural science education is the base of technology development, while technology supports the development of science.

The quality forming process is fundamental to do through the science learning process. For that reason, the learning quality in science learning is essential in order to motivate students' so that they can develop their skills and think about the scientific process (Ardhana, 2002). Science learning also trains the thinking ability in high order, such as logical, critical, creative, and innovative thinking, problem-solving, the ability in making an 
appropriate decision, and the ability in science technology which will lead to the shaping of the students' science literacy (Liliasari, 2011).

Science literacy is an ability owned by a person in understanding, at this point is to understand the scientific concepts and their processes, communicating, and the ability to apply the science to solve the problem (Yuliati, 2017).

Science literacy is categorized into four dimensions: science application context, competencies, knowledge, and attitudes (OECD, 2007). The science process has a vital role in science literacy because, in this process, a person can involve directly in the scientific method, it is to prove the scientific concepts, construct the scientific knowledge, and train the communication skills based on the obtained data and fact from science process.

Referring to the fact that it happened in Indonesia, according to the Programme for International Student Assessment (PISA), Indonesia is in the sixty-ninth rank from seventysix participating countries (OECD, 2016). It is known generally that the average of Indonesian students' science skills has not been able to relate between knowledge and its application, which affects students' competencies. In line with that (Utami, 2018) reveals that the science literation profile of junior high school students in Purwokerto is still low, where the test result shows that the students' science content ability is $53.80 \%$, the science processability is $44.03 \%$, and the students' science context ability is $35.088 \%$. Following the result released by PISA, the average result of science literacy skills is also categorized as low. It is revealed towards the research conducted by Wardhani, Situmorang, \& Sastrodihardjo (2018) that the science literacy competency is categorized as fair with the average $66,67 \%$, while the research conducted by Pratiwi, Situmorang, \& Krave (2018) in SMA Kristen 1 Salatiga revealed that it is needed to design a suitable learning model to increase students' science literacy competency.

The facts presented above give a picture that the scientific understanding of students in Indonesia is still categorized as low. It also shows the learning process, which is not optimal. The deep scientific understanding from the students is often related to the restricted motivation, horizon, and creativity of the educators. Besides that, the learning process which is lacked direction to the students' participation activity and focused on the material delivering target so that it does not give a meaningful learning experience to the students (Priyambodo \& Situmorang, 2017). The data released by The Ministry of Education in Indonesia shows that the students' concept mastery based on the 2016/2017 Academic Year Biology National Examination Result is still categorized as low. It is $40 \%$ at the national level and $47.13 \%$ in Central Java and $56.42 \%$ in plant tissue material.

Based on that fact, educators need to apply a precise strategy and innovations in the learning process to optimize the students' competence achievement. The development of students' worksheets is considered as one of the efforts to motivate students to do scientific observation so that it can build students' knowledge of the concept learned in Biology subject. The students' worksheet includes the activity which is must be done by students to maximize their understanding along with the learning indicator achievement (Trianto, 2009). The development conducted on students' worksheet needs to be supported with scientific approach-based learning model.

The inquiry is one of the scientific-based learning models. It is characterized by a process done to find and understand information towards systematical, critical, logical, and analytical findings so that the students' can formulate their findings (Trianto, 2009). The application of the inquiry learning model encourages students' direct involvement in the scientific process so that they can increase science understanding. Wenning (2011) classifies inquiry-based learning to some levels, and one of the levels is inquiry laboratory. In this level, students can establish the concept based on conducted scientific examination towards teamwork to build their knowledge.

There are three types of inquiry lab: guided inquiry lab, bounded inquiry lab, and free inquiry lab (Wenning, 2011). Guided inquiry lab is characterized by teacher's direct involvement in a whole part in guiding the students building their knowledge, while the bounded inquiry lab is typified with the pre-lab activity, which still needs teacher's involvement. The teacher's involvement is limited in identifying the main problem. The free 
inquiry lab is indicated with the direct identification of the research problem done by the students so that the students are able to build their knowledge.

The inquiry lab model application encourages students' active involvement in the learning process. It is relevant to the research result by Suryanto, Susanti, \& Saputro (2015), which shows that the free inquiry model gives a positive result towards higher students' learning achievement in the experimental class along with 80.22 and it is compared with control class 72.53 . It is supported by the free inquiry model which gives complete freedom to students to dig and find the answers through an experiment for solving the problem so that it is able to form and build students' scientific concept finding process, though the other learning media or tool is needed to help students in finding the concepts. Besides that, the similar research conducted by Sulistiawan, Sumardi, \& Berman (2017) states that the application of levels inquiry model is able to increase students' achievements in all aspects such as cognitive, affective, and psychomotor. This model encourages students to find their concepts related to material through a set of the scientific process.

If it is correlated with the science dimension process, therefore it is assumed that the free inquiry lab has the real connection as one of the learning models, which can increase students' dimensions in the science literacy process. The plant tissue topic contains the concept of constitutive, structure, and the purpose of each plant's constitutive tissue. The primary competency that the student should achieve is that the students should be able to apply the concept of the correlation between the plant's cell tissue structure and the purpose of the plant's organ based on the observation result.

Consequently, teachers need to design an activity that can facilitate students to achieve that competency. The development of free inquiry lab-based students' worksheet is one of the appropriate solutions to be applied for the presence of students' worksheet can direct students in conducting an experiment related to the identification of plant's constitutive tissue. In contrast, a free inquiry lab encourages students to involve directly and actively in a scientific experiment to build their knowledge on that topic. It will lead to the shaping of students' science literacy. This research is conducted to develop and verify the effectivity of free inquiry lab-based students' worksheets in enhancing the dimension in the science literacy process for the students of SMA Kristen 1 Salatiga.

\section{Method}

The research is conducted using the research and development method, which is adapted from the steps in Borg and Gall's theory of Research and Development (R\&D) (Borg, W. R \& Gall, 2003). It is directed for generating a product that is free inquiry lab-based students' worksheet for senior high school students. The steps conducted in this research covers the preliminary studies and collecting information, planning, and designing, making free inquiry lab-based students' worksheet, product validation I (internal review) by the lecturer expertise in the topic and learning media, product validation II (external review) by the teacher teaching the Biology subject for Senior High School Students, a limited trial which covers legibility test by six students of XI MIPA and limited trial in the small group participated by ten students. The next step is to conduct a product effectivity test towards the application of free inquiry lab-based students' worksheets to the students of XI MIPA 1 SMA Kristen 1 Salatiga.

The product trial is conducted by applying the draft of free inquiry lab-based students' worksheets in the learning process. After that, the observation is conducted. The product trial is conducted with using the One Group Pre-test \& Post-test (Sugiyono, 2010).

The subjects of the trial are the students of XI MIPA from SMA Kristen 1 Salatiga in the first semester of the 2018-2019 academic year. The subjects of the trial in the research and development are six students participating in the legibility test, ten students participating in limited trial (small group), and 24 students from XI MIPA 1 participating in product effectivity test.

The data collection process uses questionnaires, observation, and written tests. The questionnaire is used in validating the developed students' worksheet so that a feasible free inquiry lab-based students' worksheet can be obtained to be implemented in the learning 
process. The observation is conducted for assessing the achievement in the dimension in the science literacy process and assessing the learning implementation. The written test is conducted to assess the achievement in students' knowledge, which covers pre-test and post-test.

The research instruments used to cover the students' worksheet validation questionnaire for expertise validator, students' worksheet validation questionnaire for students, the observation sheet for observing the achievement in the dimension in science literacy process, learning achievement observation sheet, and the science literacy questions as the test for seeing students' learning result.

The technique in analyzing the data covers the analysis of product validation developed using the descriptive quantitative analysis based on the validation result, response, and the validators commentary through the students' worksheet. The analysis of learning implementation is done based on the observation result by the observer through the total percentage from the learning syntax in the lesson plan. The analysis of the achievement in the dimension in students' science literacy is conducted based on the final score obtained by each student. This accumulative score is the amount of the total score from each component/science process assessment aspect used in the assessment. The effectivity analysis of free inquiry lab-based students worksheets towards the enhancement in the dimension in students' science literacy process is done using paired samples t-test with the assistance of the SPSS 18.0 version. This effectivity test is the analysis prerequisite test, which covers the normality test and homogeneity test. For the next step, the hypothesis with paired samples T-Test is conducted.

\section{Result and Discussion}

\subsection{The Feasibility of Free Inquiry Lab-Based Students' Worksheet}

The feasibility result of the free inquiry lab-based students' worksheet is obtained based on the assessment result from the expertise validator and the assessment from the students toward the students' worksheet, which has been developed and applied in the learning process of plant tissue topic for XI MIPA 1 students. The free inquiry lab-based student worksheet was developed using the development steps adapted from the development model proposed by Borg, W. R \& Gall (2003), though the steps were not applied in whole regarding the time limitation and the research expense. It is relevant to what is proposed by Ardhana (2002), which states that in the developing process, we are able to choose the most suitable steps based on the condition which we face. A learning tool is considered as feasible if they fulfill the validity standards based on the assessment from the experienced validator (Prihantya, Mitarlis, \& Maulida, 2016). Here is the feasibility test result of the free inquiry lab-based students worksheet in detail :

Table 1: The Assessment Result of The Feasibility in Free Inquiry Lab-Based Students

\begin{tabular}{clcc}
\hline No. & Assessment Aspects & $\mathbf{P}(\%)$ & Category \\
\hline 1. & Preface & 72,92 & Feasible \\
2. & Content & 79,17 & Very Feasible \\
3. & Utilization & 72,92 & Feasible \\
4. & Assignment/Evaluation/Assessment & 85,71 & Very Feasible \\
\hline \multicolumn{2}{c}{ Average } & $\mathbf{7 7 , 6 8}$ & Very Feasible \\
\hline
\end{tabular}

Table 1 above shows the feasibility assessment result of the free inquiry lab-based students' worksheet by validators based on the percentage of each assessment indicators with the total average $77,68 \%$ which can be categorized as very feasible, or in other words the students' worksheet with the topic plant tissue has been very feasible to be applied in the learning process. Besides the assessment in the percentage number, the validator expertise in plant tissue topic also gives suggestions with the clarity of the material, and the choice of the plant used as the practice material. The plant should be natural to get in the surroundings as much as possible. It is in line with the conducted research where the 
teacher needs to design a learning activity that is related to the reality through a contextual phenomenon or related with surroundings (Chamany, Allen, \& Tanner, 2006). Besides that, validators' expertise in the material suggests related to the needs of illustration or description on plant tissue by the students'. It can help students along the identification process. A learning device, including the students' worksheet, will be better and effective if it is completed with the illustration as the real picture of the discussed concept (Toharudin, Hendrawati, \& Rustaman, 2011). It was also stated Shabiralyani, Hasan, Hamad, \& Iqbal (2015), say that using visuals illustration as a teaching method stimulates thinking and improves the learning environment in a classroom. Students develop and increase their personal understanding of the areas of learning when they experience successful and pleasant learning in the classroom.

Table 2: The Feasibility Assessment Result of Free Inquiry Lab-Based Students

\begin{tabular}{clcc}
\hline No. & \multicolumn{1}{c}{ Assessed Aspects } & $\mathbf{P}(\%)$ & Category \\
\hline 1. & Physical Appearance & 90,63 & Very Feasible \\
2. & Attractiveness & 93,75 & Very Feasible \\
3. Utilization & & 75,00 & Very Feasible \\
4. & Feedback & 71,43 & Feasible \\
\hline & Average & $\mathbf{8 2 , 7 0}$ & Very Feasible \\
\hline
\end{tabular}

Based on the result revealed in Table 2 above, it can be known that the feasibility assessment result of the students' worksheet by the validators' expertise in learning media is very feasible, with the total average $82,70 \%$. In other words, the students' worksheet as the learning media assessed through the assessment aspects on the table above has been very feasible to be applied in the learning process.

Nevertheless, validators' expertise in learning media also gives suggestions to clarify the character of the free inquiry lab from the students' worksheet, which will become the particular characteristic of the developed students' worksheet. This developed students' worksheet is a learning device integrated with the free inquiry lab model so that the implication will align with the learning phases in the free inquiry lab phases. All suggestions or inputs from various validators are used as an evaluation for the revision of the students' worksheet in maximizing the development of free inquiry lab-based students worksheet products.

After the students' worksheet has been revised and has been stated as feasible, the legibility test is conducted. Six students from XI MIPA 2 participated in this test. Ten students from XI MIPA 1 participated in the restriction test. From the conducted trial, later, the students will do the assessment based on the aspects stated in the questionnaire. The result of the students' assessment towards the students' worksheet is described as below:

Table 3: The Students' Response Towards Free Inquiry Lab-Based Students Worksheet

\begin{tabular}{|c|c|c|c|}
\hline No. & Assessed Aspects & $\mathbf{P}(\%)$ & Category \\
\hline 1. & Visual & 83,33 & Very Good \\
\hline 2. & Utilization & 81,25 & Very Good \\
\hline 3. & Construction & 86,46 & Very Good \\
\hline \multirow[t]{2}{*}{4.} & Content & 78,91 & Very Good \\
\hline & Average & 82,49 & Very Good \\
\hline
\end{tabular}

Based on the result obtained as described in Table 3, it can be known that students' have an excellent response, proved with the assessment average in every assessment aspects, $82,49 \%$, or in other words, the students' response has a positive response from the students as the students' worksheet implementation subject which directly interacts with the students' worksheet towards a series of activities in the worksheet.

It also can be seen from students' written responses that, generally, students are assisted in understanding the concept of plant tissue towards the implementation of the free 
inquiry lab-based students' worksheet in the learning process. It is in line with the essence of the designing process of students' worksheets, which is basically to assist students in finding a concept, correlating the concept has been learned and found through a series of activities in it (Martiyono, 2012). Teachers need to design the students' worksheets as well as possible so that the worksheet can facilitate the students, enhance the learning activity, encourage the students to be able to work individually and guide the students to the concept development (Hamdani, 2011).

\subsection{Learning Model Implication}

The validated and revised free inquiry lab-based students' worksheets later implied in a class. The result of the free inquiry lab learning implication is described in the graphic below:

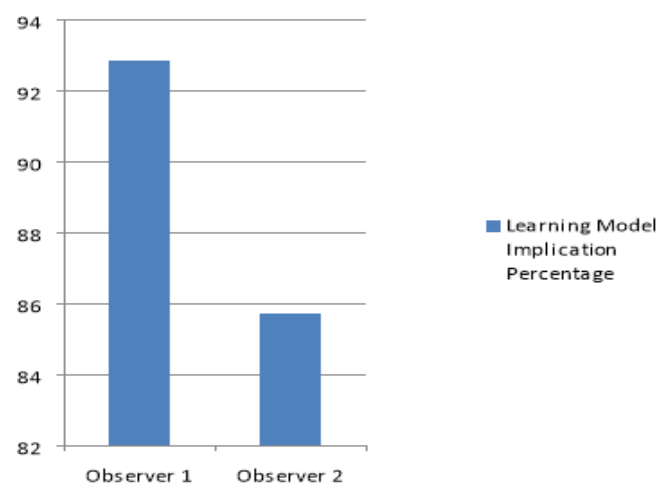

Figure 1: Learning Model Implication Percentage

Based on the graphic in Figure 1, it can be known that almost all aspects planned in the lesson plan had been implemented based on the observation done by the observer. It is shown in the graphic based on the observation done by the observers. The observation done by the Observer 1 shows that there are 13 indicators implicated from 14 implication indicators $(92,86 \%)$, while the observation done by the Observer 2 shows that there are 12 indicators implicated from 14 implication indicators in the learning model $(85,71 \%)$.

\subsection{The Achievement of The Dimension in Science Literacy Process}

The achievement of the dimension in the science literacy process is measured through the observation sheet that contains assessment indicators based on the implication trial of the free inquiry lab-based students' worksheet in the learning process towards 20 students of XI MIPA 1. The achievement of the dimension in the science literacy process is described below.

Table 4: The Result of The Achievement for The Dimension in The Science Literacy Process

\begin{tabular}{clcc}
\hline No. & Science Process Indicators & $\mathbf{P}(\%)$ & Category \\
\hline 1. & Formulating Hypothesis & 82,08 & Very Good \\
2. & Conducting an Experiment & 85,42 & Very Good \\
3. & Observing & 90,42 & Very Good \\
4. & Data Interpreting & 88,33 & Very Good \\
5. & Applying the Concept & 90,42 & Very Good \\
6. & Communicating & 89,58 & Very Good \\
\hline \multicolumn{2}{c}{ Average } & $\mathbf{8 7 , 7 1}$ & Very Good \\
\hline
\end{tabular}

According to the results obtained in Table 4, it shows that these students' worksheets can give an excellent result in terms of the dimension in students' science literacy process. It is proved with the students' achievement average in every indicator, $87,71 \%$, with the 
category excellent. The indicators of measured dimension in students' science literacy process are based on the indicators of the scientific process in general, as stated in the table above (Malik, Kurnia, \& Siti, 2017). The indicators in the table above become the base of the students' science process assessment, which is measured along the biology learning process by implementing free inquiry lab-based students' worksheet to conduct an observation/experiment of plant tissue so that students can find their concept. It is in line with the essence of the science dimension process as the form of development and enhancement of students' science processability through experiments. Besides that, (Chebii, Wachanga, \& Kiboss, 2012) states that experiment or direct trial through practical activity encourages curiosity so that students are challenged to do trials for being more active in the Biology learning activity.

The presence of students' worksheets as a learning device integrated with the steps of free inquiry lab, if it is linked with the dimension in the science literacy process, has a robust correlation. It can be seen from the result obtained above. Students' worksheet is useful to increase the activity of students in the learning process (Piawi, K.M, \& Mawardi, 2018). As the inquiry which is designed to courage the students directly to the scientific process (Trianto, 2009), the free inquiry lab-based students' worksheet facilitates the students to be actively involved in the scientific experiment process to build their knowledge about the plant tissue which affects the students' science literacy, especially in the science process dimension. It is supported by the steps in free inquiry lab Joyce \& Weil (2000), which covers the problem exposition, data collection and verification, conducting an experiment, formulating an explanation/concept, and the inquiry process analysis. They direct students to do scientific investigation independently without direction before conducting the activity, yet the students will do based on the designed students' worksheet and integrated with the free inquiry lab model. It also becomes the distinctive characteristic of the free inquiry lab at once. It will lead to the enhancement of the dimension in the students' science literacy process.

\subsection{The Effectivity of Free Inquiry Lab-Based Students' Worksheet towards The} Enhancement in Science Literacy Process

The effectivity of free inquiry lab-based students' worksheet towards the enhancement of dimension in science literacy process is measured based on the achievement in the dimension in students' science literacy process supported with the Gain Standard Value, and it is the deviation between the pre-test score and the post-test score gained by the students after implementing the free inquiry lab-based students' worksheet in the learning process. The result obtained is described as follows.

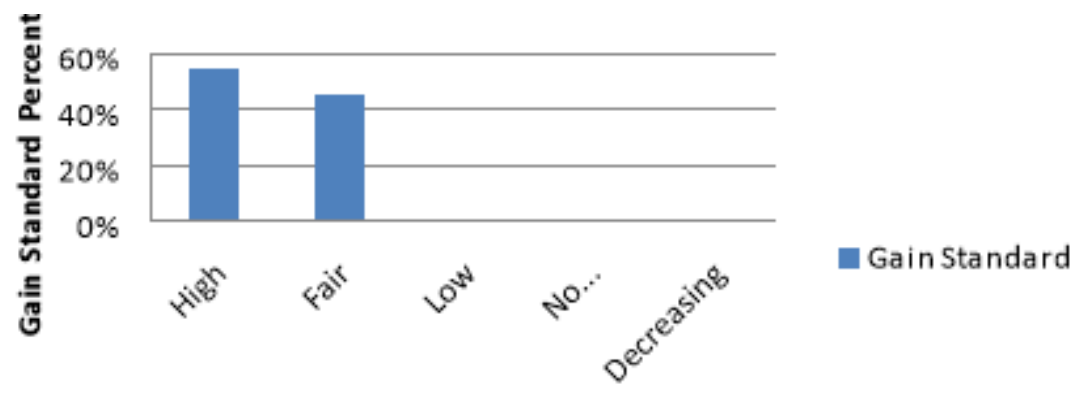

Gain Standard Category

Figure 2: Students' Enhanced Learning Result

Based on the graphic in the second picture, it can be known that overall there is an enhancement from students' learning results showed by the enhancement average from students' pretest and post-test, 35,18, and the average of overall students N-Gain, 0,7 . It can be interpreted as a high category. Twenty students in XI MIPA 1 experience the enhancement with the students' N-Gain percentage value categorized as high $55 \%$, and the 
middle category is $45 \%$. It means the implementation of free inquiry lab-based students worksheet gives a positive impact towards students' learning achievement because it facilitates students in a set of the scientific process which encourages the students to be able to find the concept on a material. It is in line with what has been stated by Trianto (2009) that in general, the inquiry process can develop all the students' potential, not only restricted to the students' skill development, but it also includes the process of formulating the problem, hypothesis, collecting and analyzing the data, and giving conclusion. Through the process, the students will realize the investigation process which they have conducted so that the learning process will give a meaningful impression for students because the chance to be actively involved in finding the concepts has been given for them.

Table 5: The Result of the Free Inquiry Lab-Based Students Worksheet

\begin{tabular}{|c|c|c|c|c|c|c|c|c|}
\hline \multirow{3}{*}{$\begin{array}{l}\text { Paired- } \\
\text { samples t- } \\
\text { test }\end{array}$} & \multicolumn{5}{|c|}{ Paired Differences } & \multirow{3}{*}{$\mathbf{T}$} & \multirow{3}{*}{ df } & \multirow{3}{*}{$\begin{array}{l}\text { Sig. } \\
(2- \\
\text { tailed) }\end{array}$} \\
\hline & \multirow[t]{2}{*}{ Mean } & \multirow[t]{2}{*}{$\begin{array}{c}\text { Std. } \\
\text { Deviation }\end{array}$} & \multirow{2}{*}{$\begin{array}{l}\text { Std. } \\
\text { Error } \\
\text { Mean }\end{array}$} & \multicolumn{2}{|c|}{$\begin{array}{l}95 \% \text { Confidence } \\
\text { Interval of the } \\
\text { Difference }\end{array}$} & & & \\
\hline & & & & Lower & Upper & & & \\
\hline $\begin{array}{c}\text { Learning } \\
\text { Result - } \\
\text { Dimension } \\
\text { Process }\end{array}$ & $7.50365 \mathrm{E}$ & 9.59388 & 2.14526 & 70.54643 & 79.52657 & 34.978 & 19 & .000 \\
\hline
\end{tabular}

The effectivity test of free inquiry lab-based students' worksheets in enhancing the dimension in students' science literacy process is conducted through a paired-sample t-test. A prerequisite test has been conducted before. This test covers the normality test and homogeneity test. This test is done by analyzing the post-test result and the score achievement average from the dimension in students' science literacy process. Because the analysis prerequisite test result has been fulfilled, then the hypothesis test can be conducted through the parametric statistic. The hypothesis test uses the paired-samples t-test, and it is obtained the value sig. (2-tailed) $0,00<0,05$, then Ho is rejected; in other words, the free inquiry lab students' worksheet is useful in enhancing the dimension in the science literacy process. It is relevant with the research that the phases in free inquiry lab encourage the students to do the scientific investigation in solving the problem and give the students comfortability to dig and find the answers so that the students can shape and build the concept finding process independently (Suryanto et al., 2015).

In line with that, Khabibah \& Suyatna (2018) also reveals that the use of inquirybased student worksheet instills generic science skill of the students. (skills for the students in the scientific process, think, and act based scientific knowledge they have. It is possible to happen because the learning activities are conducted through the experiments; the students have to play a vital role in proving the hypotheses they have designed. The students are involved in an inquiry process that included all the inquiry skills, namely: identifying problems, formulating hypotheses, designing an experiment, gathering and analyzing data, and drawing conclusions about scientific problems and phenomena. They were encouraged to discuss their ideas about scientific phenomena based on their science experiment. While performing the inquiry activity, the students practiced their metacognitive abilities in various stages of the inquiry process (Kipnis \& Hofstein, 2008).

Besides, the learning process using the students' worksheet integrated with the free inquiry lab model can enhance the students' ability in the science literacy process. It is because the product can facilitate students in doing scientific investigation so that the students do learn not only the concept but also train the students' process in finding a concept that will lead to the forming of the dimension in students' science literacy process (Wenning, 2010). 


\section{Conclusion and Suggestion}

Based on the result and the discussion above, it can be concluded that the developed free inquiry lab-based students worksheet is feasible and effective to enhance the dimension in the science literacy process for students of XI MIPA 1 based on the feasibility assessment from expertise validators. The students' response through the students' worksheet is excellent so that it can be implemented in the class learning process. It is supported by the students' average of the dimension in science literacy process 87,71 (very good) and the N-Gain average 0,7 (very good) and also proved with the statistic test paired sample t-test.

Teachers need to develop a learning device or model which can enhance students' science literacy, especially the dimension in the science literacy process. Similar research to enhance students' ability in science literacy needs to be conducted in another learning topic.

\section{References}

Ardhana, W. (2002). Konsep Penelitian Pengembangan dalam Bidang Pendidikan dan Pembelajaran. Malang: Universitas Negeri Malang.

Arikunto, S. (2010). Prosedur Penelitian: Suatu Pendekatan Praktik (Edisi Revisi). Jakarta: Rineka Cipta. Jakarta: Rineka Cipta.

Borg, W. R \& Gall, M. D. G. (2003). Education Research. Education Research. New York: Allyn and Bacon.

Chamany, K., Allen, D., \& Tanner, K. (2006). Making Biology Learning Relevant to Students: Integrating People, History, and Context into College Biology Teaching. CBE Life Sciences Education, 7(7), $267-278$.

Chebii, R., Wachanga, S., \& Kiboss, J. (2012). Effects of Science Process Skills Mastery Learning Approach on Students' Acquisition of Selected Chemistry Practical Skills in School. Scientific Research. Scientific Research, 3(8), 1291 - 1296.

Hamdani. (2011). Strategi Belajar Mengajar. Bandung: Pustaka Setia.

Hermita, R., Suciati, \& Rinanto, Y. (2016). Pengembangan Modul Berbasis Bounded Inquiry Lab untuk Meningkatkan Literasi Sains Dimensi Konten pada Materi Sistem Pencernaan Kelas XI. Jurnal Inkuiri, 5(2), 94-107.

Joyce, B., \& Weil, M. (2000). Models of Teaching. Journal of Chemical Information and Modeling. Amerika: A Person Education Company.

Khabibah, N., \& Suyatna, A. (2018). The Use of Inquiry-Based Student Worksheet To Instills Science Generic Skill of The Students. International Journal of Research, 6(6), 131138. https://doi.org/10.5281/zenodo.1301176

Kipnis, M., \& Hofstein, A. (2008). The Inquiry Laboratory as a Source for Development of Metacognitive Skills. International Journal of Science and Mathematics Education, 6(3), 601-627. https://doi.org/10.1007/s10763-007-9066-y

Liliasari. (2011). Membangun Masyarakat Melek Sains Berkarakter Bangsa Melalui Pembelajaran. In Prosiding Seminar Nasional FMIPA UNNES (pp. 1-9). Semarang: FMIPA Unnes.

Malik, A., Kurnia, E., \& Siti, R. (2017). Peningkatan Keterampilan Proses Sains Siswa melalui Context Based Learning. Jurnal Penelitian \& Pengembangan Pendidikan Fisika, 2(1), 23-30. https://doi.org/10.21009/1.02104

Martiyono. (2012). Perencanaan Pembelajaran Suatu Pendekatan Praktis Berdasarkan KTSP Termasuk Model Tematik. Yogyakarta: Asjawa Pressindo.

Mukminan. (2014). Peningkatan Kualitas Pembelajaran Pendayagunaan Teknologi Pendidikan. In Tantangan Pendidikan di Abad 21 (pp. 1-11). Surabaya: Prodi Teknologi Pendidikan Program Pascasarjana Universitas Negeri Surabaya.

OECD. (2007). First Result From PISA 2003. Paris: OECD publishing.

OECD. (2016). PISA 2015 Assessment and Analytical Framework - Science, Reading, Mathematic and Financial Literacy. Paris: OECD publishing.

Piawi, K., K.M, U., \& Mawardi. (2018). Development of Student Worksheet Based on Guided Inquiry with Class Activity and Laboratory in Thermochemistry Material. Proceedings of International Converention on Education. In International Conference of Social Science 
and Technology (pp. 669-673). Padang: Universitas Negeri Padang.

Pratiwi, F. L., Situmorang, R. P., \& Krave, A. S. (2018). Hubungan Kemampuan Literasi Sains dengan Sikap IImiah Siswa Kelas XI MIPA SMA Kristen 1 Salatiga Pada Materi Sistem Gerak yang Diuji Menggunakan Problem Based Learning. In Seminar Nasional Biologi Dan Pendidikan Biologi Uksw 2018 (pp. 301-307). Salatiga: Fakultas Biologi Universitas Kristen Satya Wacana.

Prihantya, T. istighfarin, Mitarlis, \& Maulida, A. N. (2016). Kelayakan Perangkat Pembelajaran Berdasarkan Masalah untuk Meningkatkan Kemampuan Literasi Sains Siswa SMP. Jurnal IImiah, 1(1), 1-7.

Priyambodo, P., \& Situmorang, R. P. (2017). Antigen Antibodi Pembelajaran. Yogyakarta: Pustaka Pelajar.

Shabiralyani, G., Hasan, K. S., Hamad, N., \& Iqbal, N. (2015). Impact of Visual Aids in Enhancing the Learning Process Case Research: District Dera Ghazi Khan. Journal of Education and Practice, 6(19), 226-233.

Sugiyono. (2010). Metode Penelitian Pendidikan Pendekatan Kuantitatif, kualitatif, dan R\&D.

Sulistiawan, F., Sumardi, K., \& Berman, E. T. (2017). Penerapan Model Pembelajaran Levels of Inquiry untuk Meningkatkan Hasil Belajar Siswa SMK. Journal of Mechanical Engineering Education, 4(1), 41-47. https://doi.org/10.17509/jmee.v4i1.7439

Suryanto, E., Susanti, E., \& Saputro, S. (2015). Efektivitas Model Pembelajaran Modified Free Inquiry (Mfi) Disertai Peer Tutoring Terhadap Prestasi Belajar Siswa Pada Materi Hidrolisis Garam Siswa Kelas Xi Semester Genap Sma N 1 Kartasura Tahun Pelajaran 2013/2014. Jurnal Pendidikan Kimia, 4(2), 89-97.

Tirtarahardja, U., \& Sulo, S. L. La. (2012). Pengantar Pendidikan. Jakarta: Rineka Cipta.

Toharudin, U., Hendrawati, S., \& Rustaman, A. (2011). Membangun Literasi Sains Peserta Didik. Bandung: Humaniora.

Trianto. (2009). Mendesain Model Pembelajaran Inovatif-Progresif. Jakarta: Kencana Prenada Media Group.

Utami, D. D. (2018). Upaya Peningkatan Literasi Sains Siswa dalam Pembelajaran IPA. In Prosiding Seminar Nasional MIPA V Banda Aceh (pp. 133-137). Aceh: FMIPA Unsyiah.

Wardhani, K. B., Situmorang, R. P., \& Sastrodihardjo, S. (2018). Profil Literasi SAins Siswa Kelas X MIPA 2 SMA Kristen 1 Salatiga Pada Materi Virus. In Seminar Nasional Biologi Dan Pendidikan Biologi Uksw 2018 (pp. 273-278). Salatiga: Fakultas Biologi Universitas Kristen Satya Wacana.

Wenning, C. J. (2010). Levels of inquiry: Using Inquiry Spectrum Learning Sequences to Teach Science. Jounal of Physics Teacher Education, 5(4), 11-19.

Wenning, C. J. (2011). The Levels of Inquiry Model of Science Teaching. J. Phys. Tchr. Educ. Online, 6(2), 9-16.

Yuliati, Y. (2017). Literasi Sains dalam Pembelajaran IPA. Jurnal Cakrawala Pendas, 3(2), $21-28$. 